\title{
Bibliography and sources
}

Files in the following archives were consulted:

Public Record Office of Northern Ireland (PRONI) Papers

The National Archives (TNA) Papers

National Archives of Scotland (NAS) Papers

Dicey Papers, Glasgow University Library

In addition, various newspapers, publications of political parties, pressure groups and official papers were consulted.

Adkins, Sir W. Ryland (1920), 'Home Rule for England', The Contemporary Review, March, pp. 326-331.

Alexander, Alan (1982), Local Government in Britain since Reorganisation, London, George Allen \& Unwin.

Alford, Robert (1963), Party and Society: The Anglo-American Democracies, Chicago, Rand McNally \& Company.

Allison, Graham (1971), Essence of Decision: Explaining the Cuban Missile Crisis, Boston, MA, Little, Brown and Company.

Ambrosini, Gaspare (1946), Autonomia Regionale e Federalismo, Rome, Tip. Dell'Universita.

Anderson, C., A. Blais, T. Donovan and L. Listhaug (2005), Losers' Consent: Elections and Democratic Legitimacy, Oxford, Oxford University Press.

Anderson, Perry (1994), 'The Invention of the Region, 1945-90', EUI Working Papers European Forum, EUF no. 94/2, Florence, European University Institute.

Andrews, Leighton (1999), Wales Says Yes: The Inside Story of the Yes for Wales Referendum Campaign, Bridgend, Seren.

Anthony, Gordon and John Morison (2005), 'Here, There, and (Maybe) Here Again: The Story of Law Making for Post-1998 Northern Ireland', in Robert Hazell and Richard Rawlings (eds), Devolution, Law Making and the Constitution, Exeter, Imprint Academic.

Arbuthnott Commission (2006), Putting Citizens First: Boundaries, Voting and representation in Scotland, Commission on Boundary 
Differences and Voting Systems, Edinburgh, the Stationery Office. Arthur, W. Brian (2000), Increasing Returns and Path Dependence in the Economy, Ann Arbor, University of Michigan Press.

Ashby, Edgar (1929), 'Regional Government: or The Next Step In Public Administration', Public Administration, vol. 7, pp. 365-375.

Bagehot, Walter (1981 [1867]), The English Constitution, London, Fontana.

Baldwin, Stanley (1926), On England, London, Philip Allan \& Co. Ltd. Balfour (1954), Report of the Royal Commission on Scottish Affairs London, HMSO, Cmnd. 9212.

Balls, Ed (2000), 'Britain's New Regional Policy', in E. Balls and J. Healet (eds), Towards a New Regional Policy: Delivering Growth and Full Employment, London, Smith Institute.

Balsom, Denis (1985), 'The Three-Wales model', in John Osmond (ed.), The National Question Again, Llandysul, Gomer.

Barnett, Joel (1982), Inside the Treasury, London, André Deutsch. Barnett, Lord (1985), Letter to the author, 8 February 1985.

Barnett, Lord (1997), 'Evidence to Treasury Select Committee', in Treasury Committee, The Barnett Formula, Second Report of Session 1997-98, HC 341 of Session 1997-98, London, Stationery Office, pp. 1-7.

Barton, Brian (1996), 'The Impact of World War II on Northern Ireland and Belfast-London Relations', in Peter Catterall and Sean McDougall (eds), The Northern Ireland Question in British Politics, Basingstoke, Macmillan.

Beetham, David (1991), The Legitimation of Power, Basingstoke, Palgrave Macmillan.

Berriedale Keith, Arthur (1940), The Constitution of England from Queen Victoria to George VI, London, Macmillan.

Bew, Paul, Peter Gibbon and Henry Patterson (1995), Northern Ireland, 1921-1994: Political Forces and Social Classes, London, Serif.

Billig, Michael (1995), Banal Nationalism, London, Sage.

Birrell, Derek and Murie, Alan (1980), Policy and Government in Northern Ireland: Lessons of Devolution, Dublin, Gill and Macmillan.

Black, Edwin and Alan Cairns (1966), 'A Different Perspective on Canadian Federalism', Canadian Public Administration, vol. 9, pp. 27-44.

Bloomfield, Kenneth (1994), Stormont in Crisis: A Memoir, Belfast, Blackstaff Press.

Bloomfield, Kenneth (2007), A Tragedy of Errors: The Government and Misgovernment of Northern Ireland, Liverpool, Liverpool University Press.

Bogaards, Matthhijs (2000), 'The Uneasy Relationship between Empirical and Normative Types of Consociational Theory', Journal of Theoretical Politics, vol. 12, pp. 395-423. 
Bogdanor, Vernon (1979), Devolution, Oxford, Oxford University Press. Bogdanor, Vernon (2004), 'Our New Constitution', Law Quarterly Review, vol. 120, pp. 242-262.

Borthwick, R.L. (1978), 'When The Short Cut May Be A Blind Alley: The Standing Committee on Regional Affairs', Parliamentary Affairs, vol. 31, pp. 201-209.

Bowman, John (1989), De Valera and the Ulster Question, 1917-1973, Oxford, Oxford University Press.

Bradbury, Jonathan (1997), 'Conservative Governments, Scotland and Wales: A Perspective on Territorial Management', in J. Bradbury and J. Mawson (eds), British Regionalism and Devolution, London, Jessica Kingsley Publishers.

Bradbury, Jonathan and James Mitchell (2007), 'The Constituency Work of Members of the Scottish Parliament and Assembly for Wales', Regional and Federal Studies, vol. 17, pp. 117-145.

Bradley, A.W. and D.J. Christie (1979), The Scotland Act, 1978, Edinburgh, W. Green and Son/Sweet and Maxwell.

Bradley, John (1996), An Island Economy: Exploring Long-term Economic and Social Consequences of Peace and Reconciliation Consultancy Studies No. 4, Dublin, Dublin Castle.

Brivati, Brian (1997), Hugh Gaitskell, London, Richard Cohen Books.

Brown, Gordon (2001), 'Enterprise and the regions', speech to UMIST, 29 January. www.hm-treasury.gov.uk/Newsroom_and_Speeches/Press/2001 /press_02_01.cfm (accessed 2 February 2001).

Brown, Gordon (2004), 'Foreword' to Treasury, Microeconomic Reform in Britain: Delivering Opportunities for All, Houndmills, Palgrave.

Brown, Gordon and Henry Drucker (1980), The Politics of Nationalism and Devolution, London, Longman.

Buckland, Patrick (1979), The Factory of Grievances: Devolved Government in Northern Ireland, 1921-39, Dublin, Gill and Macmillan.

Bulpitt, Jim (1983), Territory and Power in the United Kingdom, Manchester, Manchester University Press.

Bunbury, Sir Henry (1957), Lloyd George's Ambulance Wagon: Being the Memoirs of William J. Braithwaite, 1911-12, London, Methuen and Co.

Burk, Kathleen (ed.) (1982), War and the State: The Transformation of British Government, 1914-1919, London, Routledge.

Butler, David and Dennis Kavanagh (1975), The British General Election of October 1974, London, Macmillan.

Butt Philip, Alan (1975), The Welsh Question: Nationalism in Welsh Politics, 1945-1970, Cardiff, University of Wales Press.

Cabinet Office (1999), Modernising Government, London, HMSO.

Callaghan, James (1973), A House Divided: The Dilemma of Northern Ireland, London, Collins. 
Callaghan, James (1987), Time and Chance, London, Collins.

Calvert, Harry (1968), Constitutional Law in Northern Ireland: A Study in Regional Government, London and Belfast, Stevens \& Sons Ltd and Northern Ireland Legal Quarterly Inc.

Cameron, Ewen (1996), 'The Scottish Highlands: From Congested District to Objective One', in T.M. Devine and R.J. Finlay (eds), Scotland in the 20th Century, Edinburgh, Edinburgh University Press.

Cameron, Lord (Chairman) (1969), Disturbances in Northern Ireland: Report Commissioned by the Governor of Northern Ireland, Belfast, HMSO, Cmd. 532.

Campaign for a Scottish Assembly (1988), A Claim of Right for Scotland, Edinburgh, CSA.

Campbell, James (1995), 'The United Kingdom of England: The AngloSaxon Achievement', in Alexander Grant and Keith J. Stringer (eds), Uniting the Kingdom? The Making of British History, London, Routledge.

Carmichael, Paul (2002), 'The Northern Ireland Civil Service: Characteristics and Trends Since 1970', Public Administration, vol. 80, pp. 23-49.

Castle, Barbara (1980), The Castle Diaries, 1974-1976, London, Weidenfeld and Nicolson.

Catterall, Peter (2003), The MacMillan Diaries: The Cabinet Years, 1950 1957, Basingstoke, Macmillan.

Cawson, A. (1992), 'Interests, Groups and Public Policy-Making: The Case of the European Consumer Electronics Industry', in J. Greenwood, J.R. Grote, and K. Ronit (eds) Organized Interests and the European Community, London, Sage.

Chappell, Edgar L. (1943), The Government of Wales, London, Foyle's Welsh Co., Ltd.

Chester, Sir Norman (1968), The Organisation of Central Government, 1914-64, London, Allen \& Unwin.

Chester, Sir Norman (1975), The Nationalization of British Industry, 1954-51, London, HMSO.

Clarke, John (1948), The Local Government of the United Kingdom, fourteenth edition, London, Sir Isaac Pitman \& Sons, Ltd.

Cochrane, Feargal (1997), Unionist Politics and the Politics of Unionism Since the Anglo-Irish Agreement, Cork, Cork University Press.

Collier, Ruth Berins and David Collier (2002), Shaping the Political Arena: Critical Junctures, the Labour Movement, and Regime Dynamics in Latin America, Princeton, NJ, Princeton University Press.

Constitution Unit (1996), An Assembly for Wales, London, The Constitution Unit.

Constitutional Convention (1989), Towards a Scottish Parliament, Edinburgh, COSLA. 
Consultative Steering Group (1998), Shaping Scotland's Parliament, Edinburgh, Scottish Office.

Cornford, James (1996), 'Constitutional Reform in the UK', in Stephen Tindale (ed.), The State and the Nations, London, IPPR.

Cosgrove, Richard (1980), The Rule of Law: Albert Venn Dicey, Victorian Jurist, London, Macmillan.

Council of Wales and Monmouthshire (1957), Third Memorandum on its activities, London, HMSO, Cmnd. 53.

Council of Wales and Monmouthshire (1959), Fourth Memorandum Government Administration in Wales, London, HMSO, Cmnd. 631.

Coupland, Sir Reginald (1954), Welsh and Scottish Nationalism: A Study, London, Collins.

Crick, Bernard (1968), 'Sovereignty', in International Encyclopedia of Social Sciences, vol. 15.

Crossman Richard (1975), The Diaries of a Cabinet Minister: vol. I Minister of Housing, 1964-66, London, Hamish Hamilton and Jonathan Cape.

Crossman, Richard (1976), The Diaries of a Cabinet Minister: vol. II, Lord President of the Council and Leader of the House of Commons, 1966-68, London, Hamish Hamilton and Jonathan Cape.

Crowther-Hunt, Lord and A.T. Peacock (1973), Royal Commission on the Constitution, vol. II: Memorandum of Dissent, London, HMSO, Cmnd. 5460-I.

Culls, R. and P. Dodd (eds) (1986), Englishness: Politics and Culture, 1880-1920, Beckenham, Croom Helm.

Cunningham, George (1989), 'Burns Night massacre', The Spectator, 18 January.

Curtice, John (2006), 'What the People Say - If Anything', in Robert Hazell (ed.), The English Question, Manchester, Manchester University Press.

D'Arcy, M. and R. MacLean (2000), Nightmare: The Race to Become London's Mayor, London, Pimlico.

Davies, John (2007), A History of Wales, London, Penguin.

Davies, Norman (1996), Europe: A History, Oxford, Oxford University Press.

Davies, Ron (1999), Devolution - A Process not an Event, Cardiff, Institute of Welsh Affairs.

Davis, J.H. (1988), Reforming London: The London Government Problem, 1855-1900, Oxford, Clarendon Press.

Day, John Percival (1918), Public Administration in the Highlands and Islands of Scotland, London, University of London Press.

Deacon, Russell (2002), The Governance of Wales: The Welsh Office and the Policy Process, 1964-99, Cardiff, Welsh Academic Press.

Denver, D., J. Mitchell, C. Pattie and H. Bochel (2000), Scotland Decides: The Devolution Issue and the 1997 Referendum, London, Frank Cass. 
DETR (1997), Building Partnerships for Prosperity, London, HMSO, CM. 3814.

Devolution Brief (2005), Why the North East said 'No': the 2004 referendum on an Elected Regional Assembly, no. 19, February.

Dicey, A.V. (1881), 'Two Acts of Union: A Contrast', Fortnightly Review, vol. 36, pp. 168-178.

Dicey, A.V. (1886), England's Case Against Home Rule, London, John Murray.

Dicey, A.V. (1887), Letters on Unionist Delusions, London, Macmillan.

Dicey, A.V. (1901), 'The Due Representation of England', National Review, vol. 38, November, pp. 359-382.

Dicey, A.V. (1923), Introduction to the Study of the Law of the Constitution, eighth edition, London, Macmillan and Co.

Dicey, A.V. (1973 [1886]), England's Case Against Home Rule, Richmond, Richmond Publishing Company edition.

Dicey, A.V. and R.S. Rait, (1920), Thoughts on the Union Between England and Scotland, London, Macmillan and Co.

Dixon, Paul (2001), 'British Policy towards Northern Ireland 1969-2000: Continuity, Tactical Adjustment and Consistent "Inconsistencies", British Journal of Politics and International Relations, vol. 3, pp. 340-368.

Dixon, Paul (2005), 'Why the Good Friday Agreement in Northern Ireland is not Consociational', Political Quarterly, vol. 76, pp. 357-367.

Donoughue, Bernard (2005), Downing Street Diary: With Harold Wilson in No. 10, London, Jonathan Cape.

Donoughue, Bernard and George Jones (2001), Herbert Morrison: Portrait of a Politician, London, Weidenfeld and Nicolson.

Drower, G.M.F. (1984), Neil Kinnock: The Path to Leadership, London, Weidenfeld and Nicolson.

Drucker, Henry (n.d.), Breakaway: the Scottish Labour Party, Edinburgh, EUSPB.

Drucker, Henry and Gordon Brown (1980), The Politics of Nationalism and Devolution, London, Longman.

Duchacek, Ivo D. (1986), The Territorial Dimension of Politics: Within, Among, and Across Nations, Boulder, CO, Westview Press.

Edwards, Andrew and Duncan Tanner (2006), 'Defining or Dividing the Nation? Opinion Polls, Welsh Identity and Devolution, 1966-1979', Contemporary Wales, vol. 18, pp. 54-71.

Edwards, David (2005), 'Thinking about Constitutions', European Essay no. 34, London, The Federal Trust.

Elliot, Sydney and W.D. Flackes (1999), Northern Ireland: A Political Directory 1968-1999, fifth edition, Belfast, The Blackstaff Press.

English, Richard (2003), Armed Struggle: A History of the IRA, London, Pan Macmillan. 
Evans, Geoffrey and Dafydd Trystan (1999), 'Why was 1997 Different? A Comparative Analysis of Voting behaviour in the 1979 and 1997 Welsh Referendums', in Bridget Taylor and Katarina Thomson (eds), Scotland and Wales: Nations Again?, Cardiff, University of Wales Press.

Evans, Gwynfor (1996), For The Sake of Wales: The Memoirs of Gwynfor Evans, Cardiff, Welsh Academic Press.

Evans, John Gilbert (2006), Devolution in Wales: Claims and Responses, 1937-1979, Cardiff, University of Wales Press.

Falconer, Lord (2006), Speech to Final Conference of the ESRC Devolution and Constitutional Change Programme, Queen Elizabeth II Conference Centre, London, 10 March: www.dca.gov.uk/speeches /2006/sp060310.htm (accessed 10 March 2006).

Farrell, Michael (1976), Northern Ireland: The Orange State, London, Pluto Press.

Faulkner, Brian (1974), Memoirs of a Statesman, London, Weidenfeld and Nicolson.

Ferguson, William (1990), Scotland: 1689 to the Present, Edinburgh: Mercat Press.

Fielding, Steve (2000), 'A New Politics?', in P. Dunleavy, A. Gamble, I. Holliday and G. Peele, Developments in British Politics 6, Basingstoke, Palgrave.

Flynn, Norman, Steve Leach and Carol Vielba (1985), Abolition or Reform?: The GLC and the Metropolitan County Councils, London, George Allen \& Unwin.

Follis, Bryan A. (1995), A State Under Siege: The Establishment of Northern Ireland, 1920-1925, Oxford, Clarendon Press.

Foulkes, David (1983), 'An Analysis of the Wales Act 1978', in D. Foulkes, J. Barry Jones and R.A. Wilford (eds), The Welsh Veto: The Wales Act 1978 \& The Referendum, Cardiff, University of Wales Press.

Garnett, Mark and Ian Aitken (2003), Splendid! Splendid!: The Authorized Biography of Willie Whitelaw, London, Pimlico.

Gay, Oonagh and James Mitchell (2007), 'Stormont, Westminster and Whitehall', in P. Carmichael, C. Knox and R. Osborne (eds), Devolution and Constitutional Change in Northern Ireland, Manchester, Manchester University Press.

Gibbon, Gwilym (1938), 'Regional Government', Public Administration, vol. 16, pp. 415-419.

Gibson, Edward Leon (1968), A Study of the Council for Wales and Monmouthshire, 1948-1966, Unpublished LLB thesis, University College of Wales, Aberystwyth.

Godson, Dean (2004), Himself Alone: David Trimble and the Ordeal of Unionism, London, HaperCollins.

Gowan, Ivor (1965), Government in Wales, Inaugural Lecture as Professor of Political Science, University College, Wales, December. 
Greer, Scott (2003), 'Policy Divergence: Will It Change Something in Greenock?', in Robert Hazell (ed.), The State and the Nations: The Third Year of Devolution in the United Kingdom, Exeter, Imprint Academic.

Griffith, J.A.G. (1979), 'The Political Constitution', Modern Law Review, vol. 42, pp. 1-21.

Griffiths, Dylan (1996), Thatcherism and Territorial Politics: A Welsh Case Study, Aldershot, Avebury.

Griffiths, James (1969), Pages From Memory, London, J.M. Dent \& Sons Ltd.

Grodzins, Morton (1966), The American System: A New View of Government in the United States, Chicago, Rand McNally.

Guthrie, R. and I. MacLean (1978), 'Another part of the periphery: reactions to devolution in an English Development Area', Parliamentary Affairs, vol. 31, pp. 190-200.

Hacker, Jacob (1998), 'The Historical Logic of National Health Insurance: Structure and Sequence in the Development of British, Canadian, and US Medical Policy', Studies in American Political Development, vol. 12, pp. 57-130.

Hadfield, Brigid (1989), The Constitution of Northern Ireland, Belfast, SLS.

Hadfield, Brigid (ed.) (1992), Northern Ireland: Politics and the Constitution, Buckingham, Open University.

Hailsham, Lord (1990), A Sparrow's Flight: Memoirs, London, Collins.

Halkier, Henrik (2006), Institutions, Discourse and Regional Development: The Scottish Development Agency and the Politics of Regional Policy, Brussels, Peter Lang.

Hall, Peter (1986), Governing the Economy: The Politics of State Intervention in Britain and France, Oxford, Oxford University Press.

Hall, Peter (1989), The Power of Economic Ideas, Princeton, Princeton University Press.

Hall, Peter (1992), 'The Movement from Keynesianism to Monetraism: an Institutional Analysis and British Economic Policy in the 1970s', in S. Steinmo, K. Thelen and F. Longstreth (eds), Structuring Politics: Historical Institutionalism in Comparative Politics, Cambridge, Cambridge University Press.

Hall, Sir Robert (chairman) (1962), Report of the Joint Working Party on the Economy of Northern Ireland, Belfast, HMSO, Cmnd. 446.

Hammond, J.L. (1938), Gladstone and the Irish Nation, London, Longmans, Green and Co.

Hanham, H.J. (1965), 'The Creation of the Scottish Office, 1881-87', Juridical Review, 1965, pp. 205-244.

Hansard (1991), The Report of the Hansard Commission on Election Campaigns, London, Hansard Society. 
Harrison, H. (1939), Ulster and the British Empire, London, Robert Hale. Harvie, Christopher (1994), Scotland and Nationalism, London, Routledge.

Hayes, Maurice (1995), Minority Verdict: Experiences of a Catholic Public Servant, Belfast, The Blackstaff Press.

Hazell, Robert (2006), 'Introduction: What is the English Question?', in Robert Hazell (ed.), The English Question, Manchester, Manchester University Press.

Hazell, Robert (2006), 'What Are The Answers To The English Question?', in Robert Hazell (ed.), The English Question, Manchester, Manchester University Press.

Heald, David (1980), Territorial Equity and Public Finances: Concepts and Confusion, Studies in Public Policy no. 75, Glasgow, University of Strathclyde.

Heasman, D.J. (1962), 'The Ministerial Hierarchy', Parliamentary Affairs, vol. 15, pp. 307-330.

Heath, Edward (1998), The Course of My Life, London, Hodder and Stoughton.

Heclo, Hugh and Aaron Wildavsky (1981), The Private Government of Public Money, Basingstoke, Macmillan.

Heffer, Simon (1999), Nor Shall My Sword, London, Weidenfeld and Nicolson.

Hennessy, Peter (1996), The Hidden Wiring: Unearthing the British Constitution, London, Indigo.

Hennessy, Thomas (1997), A History of Northern Ireland, 1920-1996, Basingstoke, Macmillan.

Herbert, Sir Edwin (1960), Report of the Royal Commission on Local Government in Greater London, 1957-1960, London, HMSO, Cmnd. 1164.

Heuston, R.F.V. (1964), Essays in Constitutional Law, second edition, London, Stevens \& Sons.

Hirschman, Albert (1970), Exit, Voice, and Loyalty: Responses to Decline in Firms, Organizations, and States, Cambridge, MA: Harvard University Press.

HMSO (1937a), Report of the Royal Commission to Investigate the Conditions of Local Government on Tyneside, Local Government in the Tyneside Area, Cmd. 5402.

HMSO (1937b), Report of the Committee on Scottish Administration (Gilmour), Cmd. 5563.

HMSO (1948), White Paper on Scottish Affairs.

HMSO (1969), Northern Ireland: Text of a Communiqué and Declaration issued after a meeting held at 10 Downing Street on 19 August 1969, Cmnd. 4154.

HMSO (1975), Our Changing Democracy. 
HMSO (1976), Devolution: The English Dimension (A Consultative Document).

HMSO (1985), Agreement Between the Government of the United Kingdom of Great Britain and Northern Ireland and the Government of the Republic of Ireland, Cmnd. 9690.

Hogg, Quintin (1978), The Dilemma of Democracy: Diagnosis and Prescription, London, Collins.

Hogwood, Brian (1994), 'Whatever Happened to Regional Government?: Developments in Regional Administration in Britain since 1979', Strathclyde Papers on Government and Politics, Glasgow, Dept. of Government, University of Strathclyde, no. 97.

Hogwood, Brian (1995), 'Regional Administration in Britain since 1979: Trends and Explanations', Regional and Federal Studies, vol. 5, pp. 267-91.

Hogwood, Brian and Peter Lindley (1980), 'Which English Regions? An Analysis of Regional Boundaries used by Government', Studies in Public Policy no. 50, Glasgow, Strathclyde University.

Home, Sir Alec Douglas (1976), The Way the Wind Blows, London, Collins.

Hood, Christopher (1991), 'Concepts of Control over Public Bureaucracies: "Control" and "Interpolable Balance", in Franz-Xaver Kauffmann (ed.), The Public Sector, New York, Walter de Gruyter.

House of Commons (2005), London Underground Public Private Partnerships, 17th Report of Public Accounts Committee 2004-05, HC 446, 9 March.

House of Lords (2001), Reviewing the Constitution: Terms of Reference and Methods of Working, First Report of the Select Committee on the Constitution, HL Paper 11, Session 2001-02.

Hughes-Parry, Sir David (Chairman) (1965), Report of the Committee on the Legal Status of the Welsh Language, London, HMSO, Cmnd. 2785. Hume, Ian (1981), 'The Welsh Experience', in John Bochel, David Denver and Allan Macartney (eds), The Referendum Experience, Scotland 1979, Aberdeen, Aberdeen University Press.

Hutchison, I.G.C. (2001), Scottish Politics in the Twentieth Century, Basingstoke, Palgrave.

Irvine of Lairg, Lord (1998), Government's Programme of Constitutional Reform, London, Constitution Unit.

Jackson, Alvin (1999), Ireland, 1798-1998, Oxford, Blackwell.

Jalland, Patricia (1979), 'United Kingdom Devolution 1910-14: Political Panacea or Tactical Diversion?', English Historical Review, no. 73, pp. 757-785.

James, Mari and Peter Lindley (1983), 'The Parliamentary Passage of the Wales Act 1978', in D. Foulkes, J. Barry Jones and R.A. Wilford (eds), The Welsh Veto: The Wales Act 1978 \& The Referendum, Cardiff, 
University of Wales Press.

Jenkins, Brian (2001), 'The Chief Secretary', in D. George Boyce and Alan O'Day (eds), Defenders of the Union: A survey of British and Irish unionism since 1801, London, Routledge.

Johnson, Nevil (2000), 'Then and Now: the British Constitution', Political Studies, vol. 48, pp. 118-131.

Johnson, Nevil (2004), Reshaping the British Constitution, Basingstoke, Palgrave Macmillan.

Jones, Edwin (1998), The English Nation, Stroud, Sutton Publishing.

Jones, G.H., B.C. Smith and H.V. Wiseman (1967), 'Regionalism and Parliament', Political Studies, vol. 38, pp. 403-410.

Jones, J. Barry and Michael Keating (1979), 'The British Labour Party as a Centralising Force', Studies in Public Policy, no. 32, Glasgow, University of Strathclyde.

Jones, J. Barry and R.A. Wilford (1983), 'The Referendum Campaign: 8 February - 1 March 1979', in D. Foulkes, J. Barry Jones and R.A. Wilford (eds), The Welsh Veto: The Wales Act 1978 \& The Referendum, Cardiff, University of Wales Press.

Jones, Peter (1994), 'Smith pledge over Scottish Parliament', Scotsman, 12 March.

Jones, R. Merfyn and Ioan Rhys Jones (2000), 'Labour and the Nation', in D. Tanner, C. Williams and D. Hopkin (eds), The Labour Party in Wales, 1900-2000, Cardiff, University of Wales Press.

Jones, Richard Wyn and Dafydd Trystan (1999), 'The 1997 Welsh Referendum Vote', in Bridget Taylor and Katarina Thomson (eds), Scotland and Wales: Nations Again?, Cardiff, University of Wales Press.

Jones, Timothy and Jane Williams (2005), 'The Legislative Future of Wales', The Modern Law Review, vol. 68, pp. 624-653.

Jordan, Grant (1979), 'The Committee Stage of the Scotland and Wales Bill (1976-77), Waverley Papers, Edinburgh, Edinburgh University.

Judge, David (2005), Political Institutions in the United Kingdom, Oxford, Oxford University Press.

Keating, Michael (1988), State and Regional Nationalism, Hemel Hempstead, Wheatsheaf.

Keating, Michael (2005), The Government of Scotland: Public Policy Making After Devolution, Edinburgh, Edinburgh University Press.

Keating, Michael and David Bleiman (1979), Labour and Scottish Nationalism, London, Macmillan.

Kellas, James (1973), The Scottish Political System, Cambridge, Cambridge University Press.

Kendle, John (1975), The Round Table Movement and Imperial Union, Toronto, University of Toronto Press.

Kendle, John (1989), Ireland and the Federal Solution: The Debate Over the United Kingdom Constitution, 1870-1921, Kingston and 
Montreal, McGill-Queen's University Press.

Kenny, Anthony (1986), The Road to Hillsborough: The Shaping of the Anglo-Irish Agreement, Oxford, Pergamon.

Kiernan, Victor (1993), 'The British Isles: Celt and Saxon', in Mikulás Teich and Roy Porter (eds), The National Question in Europe in Historical Context, Cambridge, Cambridge University Press.

Kilbrandon, Lord (1973), Report of the Royal Commission on the Constitution, London, HMSO, Cmnd. 5460.

King, Anthony (2001), Does the United Kingdom Still Have a Constitution?, London, Sweet \& Maxwell.

Labour Party (1962), Signposts to the New Wales, London, Labour Party. Labour Party (1974), Britain Will Win With Labour, London, Labour Party.

Labour Party (1992), It's Time to Get Britain Working Again, London, Labour Party.

Labour Party (1995), A Parliament for Scotland: Labour's Plan, Glasgow, Labour Party.

Labour Party (1996), A New Voice for England, London, Labour Party.

Labour Party (1997), Britain Will Be Better With New Labour, London, Labour Party.

Labour Party in Wales (1970), Memorandum Submitted by the Labour Party in Wales to the Kilbrandon Commission, Minutes of Evidence V, 26-27 June, London, HMSO.

Lang, Ian (2002), Blue Remembered Years, London, Politicos.

Laski, Harold (1948), The Grammar of Politics, fifth edition, London, Allen \& Unwin.

Lawrence, R.J. (1965), The Government of Northern Ireland: Public Finance and Public Services, 1921-1964, Oxford, Clarendon Press.

Lee, J.J. (1990), Ireland: 1912-1985, Cambridge, Cambridge University Press.

Lessing, Doris (1994), Prisons we Choose to Live Inside, London, Flamingo.

Levi, Margaret (1997), 'A Model, a Method, and a Map: Rational Choice in Comparative and Historical Analysis', in Mark I. Lichbach and Alan S. Zuckerman (eds), Comparative Politics: Rationality, Culture and Structure, Cambridge, Cambridge University Press.

Lijphart, Arend (1977), Democracy in Plural Societies, New Haven, CT, Yale University Press.

Lijphart, Arend (1996), 'The Framework Documents on Northern Ireland and the Theory of Power Sharing', Government and Opposition, vol. 31, pp. 267-275.

Lipset, S.M. and S. Rokkan (1967), 'Cleavage Structures, Party Systems, and Voter Alignments: An Introduction' in S.M. Lipset and S. Rokkan (eds), Party Systems and Voter Alignments: Cross-National Perspec- 
tives, New York, Free Press.

Lipsky, Martin (1980), Street-Level Bureaucrats, New York, Russell Sage.

Lodge, Guy and James Mitchell (2006), 'Whitehall and the Government of England', in Robert Hazell (ed.), The English Question, Manchester, Manchester University Press.

Low, Sidney (1904), The Governance of England, London, T. Fisher Unwin.

Lowther, Speaker T.W. (1920), Conference on Devolution: Letter from $\mathrm{Mr}$ Speaker to the Prime Minister, London, HMSO, Cmd. 692.

MacCormick, James and Wendy Alexander (1996), 'Firm Foundations Securing the Scottish Parliament', in Stephen Tindale (ed.), The State and the Nations: The Politics of devolution, London, IPPR.

MacCormick, Neil (1978), 'Does the United Kingdom have a Constitution? Reflections on MacCormick v. Lord Advocate', Northern Ireland Legal Quarterly, vol. 29, pp. 1-20.

MacCormick, Neil (1999), Questioning Sovereignty, Oxford, Oxford University Press.

MacDonald, Henry (2000), Trimble, London, Bloomsbury.

MacDonald, Mary and Adam Redpath (1979), 'The Scottish Office, 1954-79', in Scottish Government Yearbook, 1979, Edinburgh, Paul Harris.

Mackenzie, W.J.M. and B. Chapman (1951), 'Federalism and Regionalism: A Note on the Italian Constitution of 1948', The Modern Law Review, vol. 14, pp. 182-194.

Mackenzie, W.J.M. and J.W. Grove (1957), Central Administration in Britain, London, Longmans.

Mackintosh, J.P. (1968), The Devolution of Power: Local Democracy, Regionalism and Nationalism, Harmondsworth, Penguin.

Mackintosh, John (1975), 'Obstacle to an Effective Assembly', Scotsman, 8 December.

Mackintosh, John (1976), 'The Power of the Secretary of State', New Edinburgh Review, no. 31, pp. 9-16.

MacPherson, Andrew and Charles Raab (1988), Governing Education: A Sociology of Policy since 1945, Edinburgh, Edinburgh University Press.

Mahoney, James (2000), 'Path dependence in historical sociology', Theory and Society, vol. 29, pp. 507-548.

Mahoney, James (2001), The Legacies of Liberalism: Path Dependence and Political Regimes in Central America, London, Johns Hopkins Press.

Mahoney, James and Dietrich Rueschemeyer (2003), 'Comparative Historical Analysis', in J. Mahoney and D. Rueschemeyer (eds), Comparative Historical Analysis in the Social Sciences, Cambridge, Cambridge University Press.

Maitland, F.W. (1900), 'Introduction', in Otto Friedrich von Gierke, Polit- 
ical Thought of the Middle Ages, Cambridge, Cambridge University Press.

Major, John (1996), Speech to Conservative Party Conference, October. Mansergh, Nicholas (1936), The Government of Northern Ireland, London, George Allen \& Unwin.

Mansergh, Nicholas (1991), The Unresolved Question: the Anglo-Irish Settlement and its Undoing, 1912-72, London, Yale University Press.

March, James G. and Johan P. Olsen (1989), Rediscovering Institutions: The Organisational Basis of Politics, New York, Free Press.

Marshall, Geoffrey (1984), Constitutional Conventions, Oxford, Clarendon Press.

Marshall, Geoffrey (2002), 'The Constitution: Its Theory and Interpretation', in Vernon Bogdanor (ed.), The British Constitution in the Twentieth Century, Oxford, Oxford University Press/The British Academy.

Marshall, T.H. (1992), Citizenship and Social Class, London, Pluto Press. Martin, R. and Tyler, P. (1991), 'The Regional Legacy of the Thatcher Years', Land Economy Discussion Paper 36, Cambridge, Department of Land Economy, University of Cambridge.

Mason, Roy (1999), Paying the Price, London, Robert Hale.

Mawson, John and Ken Spencer (1997), 'The Origins and Operation of the Government Offices for the Regions', in J. Bradbury and J. Mawson (eds), British Regionalism and Devolution, London, Jessica Kingsley Publishers.

May, John (1973), 'Opinion Structure of Political Parties: The Special Law of Curvilinear Disparity', Political Studies, vol. 21, pp. 135-151.

McAllister, Laura (1998), 'The Perils of Community as a Construct for the Political Ideology of Welsh Nationalism', Government and Opposition, vol. 33, pp. 497-517.

McAllister, Laura (2005), 'Proving the Potential of Independent Commissions: A Critical Review of the Richard Commission on the Powers and Electoral Arrangements of the National Assembly for Wales', Pubic Management, vol. 83, pp. 493-512.

McCrone, Gavin (1976), Regional Policy in Britain, fifth impression, London, George Allen \& Unwin.

McCrone, Gavin (1985), 'The Role of Government', in Richard Saville (ed.), The Economic Development of Modern Scotland, 1950-1980, Edinburgh, Edinburgh University Press.

McDonald, J.F. (1979), 'The Lack of Political Identity in English Regions: Evidence from MPs', Studies in Public Policy, no. 33, Glasgow, Strathclyde University.

McGarry, John and Brendan O'Leary (1995), Explaining Northern Ireland, Oxford, Blackwell.

McGarry, John and Brendan, O’Leary (2006a), 'Consociational Theory, 
Northern Ireland's Conflict, and its Agreement. Part 1. What Consociationalists can learn from Northern Ireland', Government and Opposition, vol. 41, pp. 43-63.

McGarry, John and Brendan O'Leary (2006b), 'Consociational Theory, Northern Ireland's Conflict, and its Agreement. Part 2. What Critics of Consociation can Learn from Northern Ireland', Government and Opposition, vol. 41, pp. 249-277.

McGilvray, James (1975), 'Sowing the seeds of conflict', Scotsman, 10 December.

McIvor, Basil (1998), Hope Deferred: Experiences of an Irish Unionist, Belfast, The Blackstaff Press.

McLean, Bob (1991), Labour and Scottish Home Rule, Part 2, Broxburn, Scottish Labour Action.

McLean, Bob (2005), Getting It Together, Edinburgh, Luath Press Limited.

McLean, Iain (1995), 'Are Scotland and Wales Over-represented in the House of Commons?', Political Quarterly, vol. 66, pp. 250-268.

McLean, Iain and Alistair McMillan (2005), State of the Union, Oxford, Oxford University Press.

McLeish, Henry (2004), Scotland First: Truth and Consequences, Edinburgh, Mainstream.

Mény, Yves and Vincent Wright (1985), 'General Introduction', in Y. Mény and V. Wright (eds), Centre-Periphery Relations In Western Europe, London, George Allen \& Unwin.

Midwinter, A., M. Keating and J. Mitchell (1991), Politics and Public Policy in Scotland, Basingstoke, Macmillan.

Millan, Bruce (Chair) (1996), Renewing the Regions: Report of the Regional Policy Commission, Sheffield, Sheffield Hallam University.

Miller, Bill, Jack Brand and Maggie Jordan (1981), 'Government Without a Mandate: its Causes and Consequences for the Conservative Party in Scotland', Political Quarterly, vol. 52, pp. 203-213.

Milne, Sir David (1957), The Scottish Office And Other Scottish Government Departments, London, George Allen \& Unwin.

Milosz, Ceslaw (1980), Nobel Lecture, New York, Farrar Straus Giroux.

Mitchell, James (1990), Conservatives and the Union, Edinburgh, Edinburgh University Press.

Mitchell, James (1992), 'Shibboleths and Slogans: Sovereignty, Subsidiarity and Constitutional Debate', in Scottish Government Yearbook 1992, Edinburgh, Unit for the Study of Government in Scotland.

Mitchell, James (1996), Strategies for Self-Government, Edinburgh, Polygon.

Mitchell, James (1997), 'Conceptual Lenses and Territorial Government in Britain' in Ulrike Jordan and Wolfram Kaiser (eds), Political Reform in Britain, 1886-1996: Themes, Ideas, Policies, Bochum, Univer- 
sitätsverlag Dr. Brochmeyer.

Mitchell, James (1998), 'The Evolution of Devolution: Labour's Home Rule Strategy in Opposition', Government and Opposition, vol. 33, pp. 479-496.

Mitchell, James (2003), Governing Scotland: the Invention of Administrative Devolution, Basingstoke, Palgrave Macmillan.

Mitchell, James (2006), 'Undignified and Inefficient: Financial Relations Between London and Stormont', Contemporary British History, vol. 20 , no. 1 , pp. $57-73$

Mitchell, James and Lynn Bennie (1996), 'Thatcherism and the Scottish Question', in British Elections and Parties Yearbook, 1995, Ilford, Essex, Frank Cass.

Molyneaux MP, James (1983), Unionist Party Conference Speech by the Leader of the Party, 19 November. Copy sent to the author by James Molyneaux.

Moore, Chris and Simon Booth (1989), Managing Competition: MesoCorporatism, Pluralism, and the Negotiated Order in Scotland, Oxford, Clarendon Press.

Morgan, Kenneth (1982), Rebirth of a Nation: Wales 1880-1980, Oxford, Oxford University Press and University of Wales Press.

Morgan, Kenneth (1989), The Red Dragon and the Red Flag: The Cases of James Griffiths and Aneurin Bevan, Aberystwyth, National Library of Wales, The Welsh Political Archive Lecture 1988.

Morgan, Kenneth (1997), Callaghan, Oxford, Oxford University Press.

Morgan, Kevin and Geoff Mungham (2000), Redesigning Democracy: The Welsh Labour Party and Devolution, Bridgend, Seren Books.

Morgan, Kevin and Ellis Roberts (1993), The Democratic Deficit: a Guide to Quangoland, Cardiff, Cardiff School of City and Regional Planning, no. 144.

Mulholland, Marc (2000), Northern Ireland at the Crossroads: Ulster Unionism in the O'Neill Years, 1960-9, Basingstoke, Macmillan.

Munro, Robert (1930), Looking Back: Fugitive Writings and Sayings, London, Oceana Publications.

Murray, Gerard (1998), John Hume and the SDLP: Impact and Survival in Northern Ireland, Dublin, Irish Academic Press.

Needham, Richard (1998), Battling for Peace, Belfast, The Blackstaff Press.

Nettl, J.P. (1968), 'The State as a Conceptual Variable', World Politics, vol. 20, pp. 559-592.

Newark, F.H. (1955), 'The Law and the Constitution', in Thomas Wilson (ed.), Ulster Under Home Rule: a Study of the Political and Economic Problems of Northern Ireland, Oxford, Oxford University Press.

New Ireland Forum (1984), Report of the New Ireland Forum, Dublin, Stationery Office. 
Newsam, Sir Frank (1954), The Home Office, London, George Allen \& Unwin Ltd.

North, Douglass (2002), Institutions, Institutional Change and Economic Performance, Cambridge, Cambridge University Press.

Northern Ireland Office (1972), The Future of Northern Ireland: A Paper for Discussion, London, NIO.

O'Day, Alan and John Stevenson (1992), Irish Historical Documents Since 1800, Dublin, Gill and Macmillan.

O'Kane, Eamonn (2004), 'Anglo-Irish Relations and the Northern Ireland Peace Process: From Exclusion to Inclusion', Contemporary British History, vol. 18, pp. 78-99.

O'Leary, Brendan (1997), 'The Conservative Stewardship of Northern Ireland, 1979-1997: Sound-bottomed Contradictions or Slow Learning?', Political Studies, vol. 45, pp. 663-676.

O'Leary, Brendan (1999), 'The Nature of the British Irish Agreement', New Left Review, vol. I/233, pp. 66-96.

O'Leary, Cornelius, Sydney Elliott and R.A. Wilford (1988), The Northern Ireland Assembly, 1982-1986: A Constitutional Experiment, London and Belfast, C. Hurst \& Company and Queen's University Bookshop.

Oliver, Dawn (2003), 'The Project: Modernizing the UK Constitution', in Dawn Oliver (ed.), Constitutional Reform in the United Kingdom, Oxford, Oxford University Press.

Oliver, John (1978), Working at Stormont, Memoirs, Dublin, Institute of Public Administration.

O'Neill, Terence (1969), Ulster at the Crossroads, London, Faber and Faber.

O'Neill, Terence (1972), The Autobiography of Terence O'Neill: Prime Minister of Northern Ireland, 1963-1969, London, Rupert HartDavis.

Orwell, George (1941), The Lion and the Unicorn: Socialism and the English Genius, London, Secker \& Warburg.

Osmond, John (2005), 'Provenance and Promise', in John Osmond (ed.), Welsh Politics Come of Age, Cardiff, Institute of Welsh Politics.

Palley, Claire (1972), 'The Evolution, Disintegration and Possible Reconstruction of the Northern Ireland Constitution', Anglo-American Law Review, vol. 1, pp. 368-476.

Parsons, Wayne (1988), The Political Economy of British Regional Policy, London, Routledge.

Patterson, Henry (2006), Ireland Since 1939, London, Penguin.

Pattie, Charles and James Mitchell (2006), 'Electoral Reform Reformed? The Arbuthnott Commission and Scottish Parliamentary Elections', Representation, vol. 42, pp. 195-208.

Peters, B. Guy (1999), Institutional Theory in Political Science: The 'New 
Institutionalism', London, Pinter.

Pierson, Paul (2000), 'Increasing Returns, Path Dependence, and the Study of Politics', American Political Science Review, vol. 94, pp. 251-267.

Pimlott, Ben (1986), Hugh Dalton, London, Jonathan Cape Ltd.

Pimlott, Ben (1992), Harold Wilson, London, HarperCollins.

Pimlott, Ben and Nirmala Rao (2002), Governing London, Oxford, Oxford University Press.

Poirier, Johanne (2001), 'The Functions of Intergovernmental Agreements: Post-Devolution Concordats in a Comparative Perspective', Public Law, pp. 134-157.

Pollak, Andy (ed.) (1993), A Citizens' Inquiry: The Opsabl Report on Northern Ireland, Dublin, The Lilliput Press.

Powell, Enoch (1996), 'Britain and Europe', in M. Holmes (ed.), The Eurosceptical Reader, Houndmills, Macmillan.

Powell, Enoch (1998), 'The Spell of England', speech given on 22 April, 1961 to dinner of the Royal Society of St George in London, reproduced in the Daily Telegraph, 9 February.

Prescott, John and Tom Pendry (1982), Alternative Regional Strategy, London, Labour Party.

Prestwich, Roger and Peter Taylor (1990), Introduction to Regional and Urban Policy in the United Kingdom, Harlow, Longman.

Pryde, George S. (1960), Central and Local Government in Scotland Since 1707, London, Cox \& Wyman Ltd.

Purdie, Bob (1986), 'The Irish Anti-partition League, South Armagh and Abstentionism', Irish Political Studies, vol. 1, pp. 67-77.

Purdie, Bob (1990), Politics in the Streets, Belfast, Blackstaff Press.

Quekett, Sir Arthur (1928), The Constitution of Northern Ireland, Belfast, HM Stationery Office.

Quigley (1976), Economic and Industrial Strategy for Northern Ireland: Report of a Review Team, Belfast, HMSO.

Rait, Robert (ed.) (1925), Memorials of Albert Venn Dicey: Being Chiefly Letters and Diaries, London, Macmillan and Co. Ltd.

Rallings, Colin and Michael Thrasher (2000), British Electoral Facts, Aldershot, Ashgate.

Randall, P.J. (1969), The Development of Administrative Decentralisation in Wales from the Establishment of the Welsh Department of Education in 1907 to the Creation of the Post of Secretary of State for Wales in October 1964, Unpublished M.Sc. thesis, University of Wales.

Randall, P.J. (1972), 'Wales in the Structure of Central Government', Public Administration, vol. 50, pp. 353-372.

Rawlings, Rick (2003), Delineating Wales: Constitutional, Legal and Administrative Aspects of National Devolution, Cardiff, University of Wales Press.

Rawlings, Rick (2005), 'Hastening Slowly: The Next Phase of Welsh 
Devolution', Public Law, pp. 824-852.

Redcliffe-Maud, Lord (Chairman) (1969), Report of the Royal Commission on Local Government in England, London, HMSO, Cmnd. 4040. Redwood, John (1999), The Death of Britain?, Basingstoke, Macmillan Press.

Reich, Robert (1998), Locked Inside the Cabinet, New York, Vintage Books.

Renan, E. (1939), 'What is a Nation?', in Zimmern, Alfred (ed.), Modern Political Doctrines, Oxford, Oxford University Press.

Richard, Lord Ivor (Chair) (2004), Commission on the Powers and Electoral Arrangements of the National Assembly for Wales, Report of the Richard Commission, Cardiff, National Assembly for Wales.

Robbins, Keith (1988), Nineteenth-Century Britain: Integration and Diversity, Oxford, Clarendon Press.

Roberts, Andrew (2000), Salisbury: Victorian Titan, London, Orion Books.

Roberts of Conwy, Lord (2006), Right From the Start: The Memoirs of Sir Wyn Roberts, Cardiff, University of Wales Press.

Rokkan, Stein (1970), Citizens, Elections, and Parties, New York, David Mackay.

Rokkan, Stein (1999), State Formation, Nation-Building, and Mass Politics in Europe: The Theory of Stein Rokkan, based on his collected works and edited by Peter Flora with Stein Kuhnle and Derek Urwin, Oxford, Oxford University Press.

Rokkan, Stein and Derek Urwin (1982), "Introduction: Centres and Peripheries in Western Europe', in Stein Rokkan and Derek Urwin (eds), The Politics of Territorial Identity: Studies in European Regionalism, London, Sage.

Rose, Peter (1996), 'Labour, Northern Ireland and the Decision to Send in the Troops', in Peter Catterall and Sean McDougall (eds), The Northern Ireland Question in British Politics, Basingstoke, Macmillan.

Rose, Richard (1971), Governing Without Consensus: An Irish Perspective, Boston, Beacon Press.

Rose, Richard (1975), Northern Ireland: A Time of Choice, Basingstoke, Macmillan.

Rose, Richard (1982), Understanding the United Kingdom, London, Longman.

Ross, Jim M. (1985), Letter to the author, 11 January.

Ross, William (1978), 'Approaching to Arch-angelic?', in Scottish Government Yearbook 1978, Edinburgh, Paul Harris Publishing.

Rowlands, E. (1972), 'The Politics of Regional Administration: The Establishment of the Welsh Office', Public Administration, vol. 50, pp. 333-351.

Rowlands, Ted (2004), 'Whitehall's Last Stand: The Establishment of the 
Welsh Office, 1964', Contemporary Wales, vol. 16, pp. 39-52.

Rowthorn, Bob (1981), 'Northern Ireland: an Economy in Crisis', Cambridge Journal of Economics, vol. 5, pp. 1-31.

Russell, Meg (2005), 'A Constitution by any other name ...', Political Quarterly, vol. 76, p. 457.

Russell, Meg and Guy Lodge (2006), 'The government of England by Westminster', in Robert Hazell (ed.), The English Question, Manchester, Manchester University Press.

Sahlins, Peter (1989), Boundaries: The Making of France and Spain in the Pyrenees, Berkeley and Los Angeles, University of California Press.

Sandford, Mark (2004), 'The Governance of London', in Alan Trench (ed.), Has Devolution Made a Difference?, Exeter, Imprint Academic.

Sandford, Mark (2005), The New Governance of the English Regions, Basingstoke, Palgrave Macmillan.

Sandford, Mark (2006), 'Facts on the Ground: the Growth of Institutional Answers to the English Question in the Regions', in Robert Hazell (ed.), The English Question, Manchester, Manchester University Press. Scottish Constitutional Convention (1989), Towards a Scottish Parliament, Edinburgh, Convention of Scottish Local Authorities.

Scottish Office (1997), Scotland's Parliament, Edinburgh, HMSO, Cm. 3658.

Scottish Unionist Party (1949), Scottish Control of Scottish Affairs, Edinburgh, Scottish Unionist Party.

Seawright, David (1999), An Important Matter of Principle: The Decline of the Scottish Conservative and Unionist Party, Aldershot, Ashgate.

Shea, Patrick (1981), Voices and the Sound of Drums, Belfast, Blackstaff. Sillars, Jim (1986), The Case for Optimism, Edinburgh, Polygon.

Smith, B.C. (1964), Regionalism in England: Regional Institutions: A Guide, London, Acton Society Trust.

Smith, Fintan (2005), The North East Referendum: Initiation and Control, dissertation submitted for award of M.Phil., Strathclyde University.

Smith, Llew (1995), The Welsh Assembly: Why It Has No Place in Wales, London, Llew Smith.

Smith, Sheriff Guthrie (1885), 'Scotland and the National Government', Journal of Jurisprudence, vol. 29, pp. 225-241.

Steel, David (2001), 'A Dozen Differences of Devolution', 4 June: www.scottish.parliament.uk/nmCentre/news/news-01/pa01-031.htm (accessed 5 July 2005).

Stewart, A.T.Q. (1981), Edward Carson, Belfast, Blackstaff.

Stewart, A.T.Q. (1989), The Narrow Ground: The Roots of Conflict in Ulster, London, Faber and Faber.

Stinchcombe, Arthur L. (1968), Constructing Social Theories, New York, Harcourt, Brace and World. 
Supreme Court (1990), McGimpsey v. Ireland, IESC 3, 1 March: www.bailii.org/ie/cases/IESC/1990/3.html (accessed 6 January 2005).

Swank, Duane (2002), Global Capital, Political Institutions, and Policy Change in Developed Welfare States, Cambridge, Cambridge University Press.

Symmons, Clive (1992), 'International Treaty Obligations and the Irish Constitution: the McGimpsey Case', International and Comparative Law Quarterly, vol. 41, pp. 311-342.

Tanner, Duncan (2006a), 'How Devolution Died: the British Labour Party's Constitutional Agenda, 1900-45', in D. Tanner, C. Williams, W.P. Griffith and A. Edwards (eds), Debating Nationhood and Governance in Britain, 1885-1939, Manchester, Manchester University Press.

Tanner, Duncan (2006b), 'Richard Crossman, Harold Wilson and Devolution, 1966-70: The Making of Government Policy', Twentieth Century British History, vol. 17, pp. 545-578.

Taylor, Charles (1993), Reconciling the Solitudes: Essays on Canadian Federalism and Nationalism, London, McGill-Queen's University Press.

Taylor, Rupert (2001), 'Consociation or Social Transformation?', in John McGarry (ed.), Northern Ireland and the Divided World: Post-Agreement Northern Ireland in Comparative Perspective, Oxford, Oxford University Press.

Taylor, Rupert (2006), 'The Belfast Agreement and the Politics of Consociationalism: A Critique', Political Quarterly, vol. 77 pp. 217-226.

Thatcher, Margaret (1993), The Downing Street Years, London, HarperCollins.

Thelen, Kathleen (2003), 'How Institutions Evolve' in James Mahoney and Dietrich Rueschemeyer (eds), Comparative Historical Analysis in the Social Sciences, Cambridge, Cambridge University Press.

Thomas, George (1985), Mr Speaker: The Memoirs of Lord Tonypandy, London, Harmondsworth.

Thomas, Ian C. (1981), 'The Creation of the Welsh Office: Conflicting Prposes in Institutional Change', Studies in Public Policy, no. 91, Glasgow, Centre for the Study of Public Policy, University of Strathclyde.

Tilly, Charles (1975), 'Reflections on the History of European State Making', in Charles Tilly (ed.), The Formation of National States in Europe, Princeton, Princeton University Press.

Tilly, Charles (1992), Coercion, Capital, and European States, AD 990 1992, Oxford, Blackwell.

Tindale, Stephen (ed.), The State and the Nations, London, IPPR.

Todd, Jennifer (1987), 'Two Traditions in Unionist Political Culture', Irish Political Studies, vol. 2, pp. 1-26. 
Tomaney, John (2006), 'The Idea of English Regionalism', in Robert Hazell (ed.), The English Question, Manchester, Manchester University Press.

Tomaney, John and Hetherington, Peter (2004), 'English Regions: The Quiet Revolution?' in Alan Trench (ed.), Has Devolution Made A Difference?, Exeter, Imprint Academic.

Tomkins, Adam (2005), Our Republican Constitution, Oxford, Hart Publishing.

Toothill, J.N. (1961), Inquiry into the Scottish Economy, Edinburgh, Scottish Council (Development and Industry).

Treasury (2004), Microeconomic Reform in Britain: Delivering Opportunities for All, Houndmills, Palgrave.

Trench, Alan (2005), 'Whitehall and the Process of Legislation after Devolution', in Robert Hazell and Richard Rawlings (eds), Devolution, Law Making and the Constitution, Exeter, Imprint Academic.

Trench, Alan (2007a), 'Old Wine in New Bottles? Wales-Whitehall Relations After the Government of Wales Act, 2006', Contemporary Wales, vol. 20, pp. 31-51.

Trench, Alan (2007b), 'Washing Dirty Linen in Private: The Processes of Intergovernmental Relations and the Resolution of Disputes' in Alan Trench (ed.), Devolution and Power, Manchester, Manchester University Press.

Trimble, David (2001), To Raise up a New Northern Ireland, Belfast, Blackstaff Press.

Trystan, Dafydd, Richard Wyn Jones and Roger Scully (2003), 'Explaining the Quiet Earthquake: Voting Behaviour in the First Election to the National Assembly for Wales', Electoral Studies, vol. 22, pp. 635-650.

Wales Office (2005), Better Governance for Wales, Cardiff, HMSO, Cm. 6582.

Walker, Graham (2004), A History of the Ulster Unionist Party: Protest, Pragmatism and Pessimism, Manchester, Manchester University Press. Wallace, Martin (1967), 'Home Rule in Northern Ireland - Anomalies of Devolution', Northern Ireland Legal Quarterly, vol. 18, pp. 159-176.

Watkins, Sir Percy E. (1944), A Welshman Remembers, Cardiff, W. Lewis Ltd.

Weight, Richard (2002), Patriots: National Identity in Britain, 19402000, London, Macmillan.

Wheare, Sir Kenneth (1963), Federalism, fourth edition, Oxford, Oxford University Press.

Whyte, John (1991), Interpreting Northern Ireland, Oxford, Clarendon Press.

Wichert, Sabine (1991), Northern Ireland Since 1945, London, Longman. Wilford, Rick and Robin Wilson (2000), 'A "Bare Knuckle Ride": Northern Ireland', in Robert Hazell (ed.), The State and the Nations: The 
First Year of Devolution in the United Kingdom, Exeter, Imprint Academic.

Wilford, Rick and Robin Wilson (2003), 'Northern Ireland: Valedictory?', in Robert Hazell (ed.), The State and the Nations: The Third Year of Devolution in the United Kingdom, Exeter, Imprint Academic.

Wilford, Rick and Robin Wilson (2005), 'Northern Ireland: While You Take The High Road ...', in Alan Trench (ed.), The Dynamics of Devolution: The State of the Nations 2005, Exeter, Imprint Academic.

Williams, D. (1950), Modern Wales, London, John Murray.

Williams, Gwyn (1991), When Was Wales?, London, Penguin.

Williams, Hywel (1998), The Guilty Men, London, Arium Press.

Wills, Michael (2006), A New Agenda: Labour and Democracy, London, IPPR.

Willson, F.M.G. (1955), 'Ministries and Boards: Some Aspects of Administrative Development Since 1832', Pubic Administration, vol. 33, pp. 43-58.

Wilson, Andrew (1995), Irish America and the Ulster Conflict, 19681995, Belfast, the Blackstaff Press.

Wilson, Robin and Rick Wilford (2001), 'Northern Ireland: Endgame', in Alan Trench (ed.), The State of the Nations 2001: The Second Year of Devolution in the United Kingdom, Exeter, Imprint Academic.

Wilson, Robin and Rick Wilford (2004), 'Northern Ireland: Renascent?', in Alan Trench (ed.), Has Devolution Made a Difference? The State of the Nations 2004, Exeter, Imprint Academic. 
James Mitchell - 9781847793270 Downloaded from manchesterhive.com at 04/26/2023 12:24:28PM via free access 